\title{
Response of adipose tissue lipoprotein lipase activity and serum lipoproteins to acute hyperinsulinaemia in man
}

\author{
H. Yki-Järvinen, M.-R. Taskinen, V. A. Koivisto and E. A. Nikkilä \\ Third Department of Medicine, University of Helsinki, Helsinki, Finland
}

Summary. In order to assess the short-term effects of hyperinsulinaemia and hyperglycaemia on adipose tissue lipoprotein lipase activity and on serum lipoproteins, we measured these variables in ten normal subjects during euglycaemic and hyperglycaemic hyperinsulinaemic clamps. The mean steadystate plasma glucose and insulin concentrations, respectively, were $4.7 \mathrm{mmol} / 1$ and $101 \mathrm{mU} / 1$ during euglycaemic moderateinsulin clamp, $4.9 \mathrm{mmol} / 1$ and $565 \mathrm{mU} / 1$ during euglycaemic high-insulin clamp, and $8.8 \mathrm{mmol} / 1$ and $148 \mathrm{mU} / 1$ during hyperglycaemic clamp. Saline infusion was used as control. The adipose tissue lipoprotein lipase activity rose significantly over $5 \mathrm{~h}$ during high-insulin clamp ( $p<0.01)$ and during hyperglycaemic clamp $(p<0.05)$, but did not change during the moderate-insulin clamp. The magnitude of change of lipoprotein lipase activity from baseline (either rise or fall) was inversely related to the preclamp activity during euglycaemic moderate-insulin clamp $(r=-0.67)$, during hyperglycaemic clamp $(r=-0.68)$ and during infusion of saline $(r=-0.75$, $p<0.05$ ). Total serum triglyceride concentration decreased significantly during all clamp studies compared with the control experiment. This change was mainly accounted for by a decrease of VLDL triglyceride. The LDL cholesterol level fell by an average of $5 \%(p<0.05)$ during the high-insulin clamp and by $10 \%(p<0.05)$ during the hyperglycaemic clamp. The HDL cholesterol level did not change significantly. It is concluded that adipose tissue lipoprotein lipase activity in man is increased by physiological insulin levels during hyperglycaemia and also by supraphysiological insulin levels during euglycaemia, but is not influenced by physiological hyperinsulinaemia without hyperglycaemia. Low basal lipoprotein lipase activity is more sensitive to insulin-glucose stimulation than primarily high lipoprotein lipase activity. Acute hyperinsulinaemia decreases VLDL triglyceride and LDL cholesterol concentrations.

Key words: Adipose tissue lipoprotein lipase, insulin, glucose, insulin sensitivity, lipoproteins.
Several studies have suggested that insulin participates in the regulation of lipoprotein lipase (LPL) activity in human adipose tissue. Insulin deficiency and insulin resistance in diabetic subjects are associated with subnormal levels of LPL which are restored with insulin treatment $[1,2]$. In healthy subjects, adipose tissue LPL decreases during fasting $[3,4]$ and increases with carbohydrate feeding [5-7]. The LPL response is related to basal LPL activity [6].

In subjects with endogenous hypertriglyceridaemia [6] and in normotriglyceridaemic subjects on chronic haemodialysis [8], the rise of LPL induced by high-carbohydrate feeding is inversely related to the basal level. Although these studies do not separate the effects of insulin from those of glucose and gut hormones, they suggest that basal LPL activity influences its responsiveness to various regulators. This was also shown by Sadur et al. [9] who found that only low LPL values in- creased during hyperinsulinaemia. It is not known, however, whether a high basal enzyme activity or the dose of insulin is the more important regulator of adipose tissue LPL activity.

In the present study we measured the effects of insulin at two plasma levels, during euglycaemia and during hyperglycaemia, on adipose tissue LPL activity. Since LPL participates in the regulation of serum levels of both VLDL and high-density lipoprotein (HDL), the response of serum lipoproteins was also examined.

\section{Subjects and methods}

\section{Subjects}

Fourteen healthy students (seven females and seven males), age range from 19 to 31 years $(22 \pm 1$ years, mean \pm SEM) were studied. Their weight (based on medium frame individuals from the Metropolitan 
Life Insurance Company standards, 1959) ranged from 93 to $114 \%$ $(103 \pm 2 \%)$ ideal body weight. All subjects were consuming a weightmaintaining diet that contained at least $200 \mathrm{~g}$ of carbohydrate/day for 3 days before each study. No subject had a family history of diabetes mellitus or lipid disorders, and none was taking any medication. Exercise histories were variable. The purpose, nature, and potential risks of the study were explained to all subjects and informed consent was obtained before their participation. The experimental protocol was approved by the Ethical Committee of the Helsinki University Hospital.

\section{Experimental protocol}

All studies were begun at $08.00 \mathrm{~h}$ after a 10 to 12 -h overnight fast. An indwelling retrograde catheter was inserted into a hand vein for blood sampling. The hand was then inserted into a heated chamber $\left(70^{\circ} \mathrm{C}\right)$ to arterialize venous blood [10]. Adipose tissue biopsies for determination of LPL activity and blood samples for lipid analyses were taken $30-45 \mathrm{~min}$ before starting glucose and insulin or saline $(0.15 \mathrm{~mol} / \mathrm{l}) \mathrm{in}-$ fusions, and these were repeated after 5-h clamp. Four protocols (A-D) were used to study the effects of insulin and/or glucose or saline on LPL activity and blood lipids. A total of 40 studies were performed in the 14 subjects. Ten subjects (five males and five females) participated in 32 studies (10 euglycaemic low-insulin (A) and six high-insulin (B) clamps, 10 hyperglycaemic clamps (C), and six saline control studies (D)). The remaining four subjects participated in a euglycaemic high-dose insulin clamp and a saline control study (eight studies). There was at least a 10-day interval between the studies.

Protocols $A$ and B: euglycaemic hyperinsulinaemic clamps at two levels of hyperinsulinaemia. The effect of two levels of hyperinsulinaemia at basal plasma glucose concentration was determined by the insulin clamp technique [11]. Priming plus continuous infusion of crystalline porcine insulin (Actrapid, Novo, Copenhagen, Denmark) were administered. The priming doses were given in a logarithmically-decreasing manner for $10 \mathrm{~min}$ to raise the plasma insulin concentration to the desired levels [100 and $600 \mathrm{mU} / 1$ in the low-insulin (protocol A, five males, five females) and high-insulin (protocol B, five males, five females) euglycaemic clamps, respectively]. Thereafter insulin was infused for $290 \mathrm{~min}$ at a constant rate of $40 \mathrm{mU} \cdot \mathrm{m}^{-2} \cdot \mathrm{min}^{-1}$ (protocol A) or $180 \mathrm{mU} \cdot \mathrm{m}^{-2} \cdot \mathrm{min}^{-1}$ (protocol B) to maintain the desired insulin level. Blood samples for determining plasma insulin concentration were taken at 30 -min intervals. Basal plasma glucose values were measured in the morning before each study. The plasma glucose was maintained at the basal level by the determination of the plasma glucose concentration from arterialized venous blood every $5 \mathrm{~min}$ and concomitant adjustment by infusion of $20 \%$ glucose solution. Under these steady-state conditions of constant hyperinsulinaemia and euglycaemia, hepatic glucose production is suppressed [11] and the amount of glucose infused (M) serves as a measure of the total amount of glucose metabolised by the body.

Protocol C: hyperglycaemic clamp with hyperinsulinaemia. In 10 subjects (five males, five females) the plasma glucose concentration was acutely raised and maintained at $4.0 \mathrm{mmol} / 1$ above basal level by a priming $\left(5.5 \mathrm{mg} \cdot \mathrm{kg}^{-1} \cdot \mathrm{min}^{-1}\right)$ and variable infusion of a $20 \%$ glucose solution. The variable infusion was started at $12-14 \mathrm{~min}$, when the 10 -min plasma glucose concentration became available. The priming $(0-10 \mathrm{~min})$ and continuous $(10-290 \mathrm{~min})$ infusions of insulin $\left(40 \mathrm{mU} \cdot \mathrm{m}^{-2} \cdot \mathrm{min}^{-1}\right)$ were given as described above in the low-dose euglycaemic clamp protocol.

Protocol D: saline control infusion. Ten subjects (five males and five females) received infusion of saline $(0.15 \mathrm{~mol} / \mathrm{l})$ for $5 \mathrm{~h}$. Plasma glucose and insulin concentrations were measured at $0 \mathrm{~h}$ and $5 \mathrm{~h}$.

\section{Assay of heparin-releasable LPL activity in the adipose tissue}

Heparin-releasable LPL activity was measured from needle-biopsy specimens. Subcutaneous adipose tissue biopsy was taken by aspira- tion from the gluteal region. The skin at biopsy sites was anaesthetized with $1 \%$ lignocaine. The tissue was taken into saline $(0.15 \mathrm{~mol} / \mathrm{l})$ at room temperature, washed, blotted, weighed and used for assay of LPL activity either immediately or after storage at $-70^{\circ} \mathrm{C}$. The activity was measured from heparin eluates of tissue pieces using labelled triolein emulsion as substrate [12]. The interassay coefficient of variation for the measurement of LPL activity of the internal milk standard averages $86 \%$ with a range of $80 \%-116 \%$ around the mean [12]. The results are expressed as $\mu \mathrm{mol}$ non-esterified fatty acids (NEFA) release $\operatorname{tin} 1 \mathrm{~h}$ by $1 \mathrm{~g}$ of tissue.

\section{Separation of lipoproteins}

The lipoprotein fractions were isolated by sequential flotation [13] in a Beckman Model L 70 ultracentrifuge (Beckman Instruments, Palo Alto, California, USA) using a Type 50.3 Ti Beckman rotor. VLDL was separated by spinning serum at a density of $1.006 \mathrm{~g} / \mathrm{ml}$ for $18 \mathrm{~h}$ at $38,000 \mathrm{rev} / \mathrm{min}$. The top layer (=VLDL) was removed by tube slicing and the density of the infranatant was adjusted to $1.063 \mathrm{~g} / \mathrm{ml}$ with a solution of $\mathrm{KBr}(354 \mathrm{~g} / \mathrm{l})+\mathrm{NaCl}(153 \mathrm{~g} / \mathrm{l})$ and the $\mathrm{LDL}$ was floated to the surface by spinning for $24 \mathrm{~h}$ at $38,000 \mathrm{rev} / \mathrm{min}$. The density of the LDL infranatant was raised to $1.125 \mathrm{~g} / \mathrm{ml}$ with the same $\mathrm{KBr}$ $\mathrm{NaCl}$ mixture and the high density lipoprotein $2\left(\mathrm{HDL}_{2}\right)$ was separated by centrifugation at $38,000 \mathrm{rev} / \mathrm{min}$ for $65 \mathrm{~h}$. After tube slicing the density of the bottom fraction was adjusted to $1.210 \mathrm{~g} / \mathrm{ml}$ with the $\mathrm{KBr}-\mathrm{NaCl}$ mixture and the $\mathrm{HDL}_{3}$ was floated to the surface by spinning for $65 \mathrm{~h}$ at $35,000 \mathrm{rev} / \mathrm{min}$. After isolation the four lipoprotein fractions were dialysed overnight against $\mathrm{NaCl}(0.15 \mathrm{~mol} / 1)$ at $+4{ }^{\circ} \mathrm{C}$ and their cholesterol and triglyceride contents were analysed.

\section{Analytical methods}

Plasma glucose was determined during the studies by the glucose oxidase method using the Beckman glucose analyser (Beckman Instruments, Clinical Instruments Division, Fullerton, California). Plasma insulin concentrations were determined by radioimmunoassay [14]. The concentration of cholesterol was determined by an enzymatic method using a commercial reagent kit (187313 of Boehringer Diagnostica, Mannheim, FRG). Triglycerides were measured by autoanalyzer using kit 297771 of Boehringer Diagnostica [15]. Serum NEFA concentration was determined according to Mosinger [16].

\section{Data analysis}

Statistical comparisons between clamp studies and saline infusion were performed using Student's t-test for unpaired observations and Pearson's linear regression analysis using Biomedical Data Processing (BMDP) computer programs $3 \mathrm{D}$ and $8 \mathrm{D}$, and program $2 \mathrm{D}$ for data description including analysis of distribution of variables [17]. Wilcoxon's rank-sum test for unpaired observations was used when distribution was not normal [18]. Statistical comparisons of baseline values between different studies were calculated with analysis of variance using BMDP computer program 7D [17]. All results are expressed as mean $\pm S E M$.

\section{Results}

\section{Plasma glucose and insulin concentrations, and total glucose metabolism during clamp studies}

Euglycaemic clamps. The fasting plasma glucose concentrations $(4.8 \pm 0.1$ and $4.5 \pm 0.1 \mathrm{mmol} / \mathrm{l})$ were maintained at $4.7 \pm 0.1$ and $4.9 \pm 0.1 \mathrm{mmol} / 1$ with coefficients of variation of $7.7 \pm 0.7 \%$ and $11.4 \pm 0.9 \%$ during lowand high-dose insulin clamps. The fasting plasma insu- 
lin concentrations $(7.0 \pm 0.6$ and $9.1 \pm 1.0 \mathrm{mU} / 1)$ increased to steady-state levels $(30-300 \mathrm{~min})$ of $101 \pm 3$ and $565 \pm 22 \mathrm{mU} / 1$ during low- and high-insulin euglycaemic clamps, respectively. The stability of the plasma insulin concentration is indicated by the coefficients of variation which were $11.6 \pm 1.9 \%$ and $12.9 \pm 1.0 \%$ in the low- and high-dose studies, respectively. The amounts

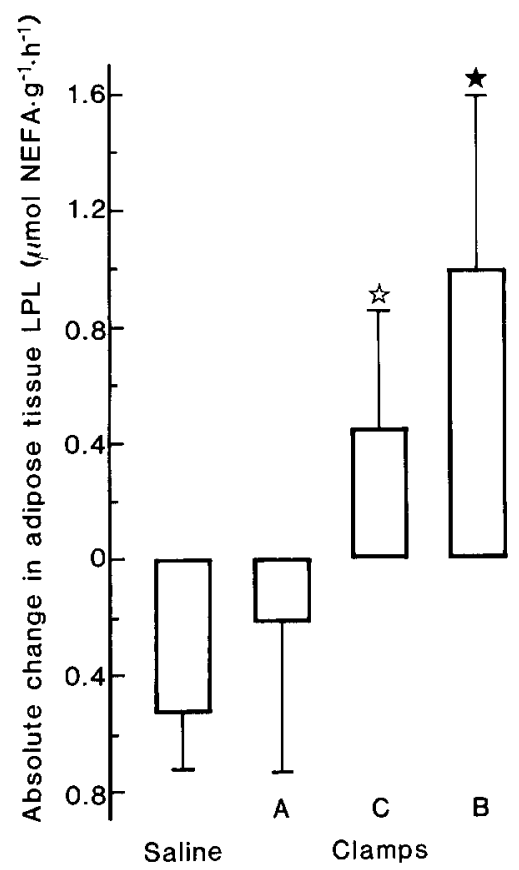

Fig. 1. Absolute change in adipose tissue LPL during infusion of saline $(n=10)$, euglycaemic low-dose $(n=10, \mathrm{~A})$ and high-dose $(n=10$, B) insulin clamps and during hyperglycaemic hyperinsulinaemia $(n=10, \mathrm{C})$. $t p<0.05, \star p<0.01$ of glucose infused during low- and high-dose euglycaemic clamp studies $(20-300 \mathrm{~min})$ were $9.88 \pm 0.63$ and $14.10 \pm 1.20 \mathrm{mg} \cdot \mathrm{kg}^{-1} \cdot \mathrm{min}^{-1}$, respectively. A direct relationship was observed between the individual values in the two euglycaemic clamps $(r=0.94, p<0.01)$.

Hyperglycaemic hyperinsulinaemic clamp. The fasting plasma glucose concentration of $4.7 \pm 0.1 \mathrm{mmol} / 1$ was elevated and maintained at $8.8 \pm 0.3 \mathrm{mmol} / \mathrm{l}$ with a coefficient of variation of $5.5 \pm 0.6 \%(20-300 \mathrm{~min})$. The fasting insulin concentration rose to $147 \pm 14 \mathrm{mU} / 1$ (30-300 min). The amount of glucose infused to maintain hyperglycaemia was $17.87 \pm 1.30 \mathrm{mg} \cdot \mathrm{kg}^{-1} \cdot \mathrm{min}^{-1}$. The rate of glucose utilization was significantly higher during hyperglycaemic clamp than during the euglycaemic high-insulin clamp $(p<0.005$, paired t-test). The individual rates of glucose metabolism during the hyperglycaemic clamp were related to the rates of glucose metabolism during the low-dose $(r=0.86, p<0.01)$ and high-dose $(r=0.94, \quad p<0.01) \quad$ insulin euglycaemic clamps.

\section{Adipose tissue LPL activity}

Basal LPL activities were $3.54 \pm 0.67,2.06 \pm 0.60$, $2.26 \pm 0.59$, and $1.78 \pm 0.37 \mu \mathrm{mol} \mathrm{NEFA} \cdot \mathrm{g}^{-1} \cdot \mathrm{h}^{-1}$ in low- (A) and high-dose (B) euglycaemic clamps, hyperglycaemic clamp (C) and saline control study (D), respectively (NS). When compared with saline controls, a significant stimulatory response of LPL was observed during the high-dose insulin clamp ( $p<0.01$, Fig. 1$)$ and the hyperglycaemic clamp $(p<0.05)$ but not during the low-dose insulin clamp. During saline infusion LPL activity fell by $30 \%$ to $1.29 \pm 0.29 \mu \mathrm{mol} \mathrm{NEFA} \cdot \mathrm{g}^{-1} \cdot \mathrm{h}^{-1}$
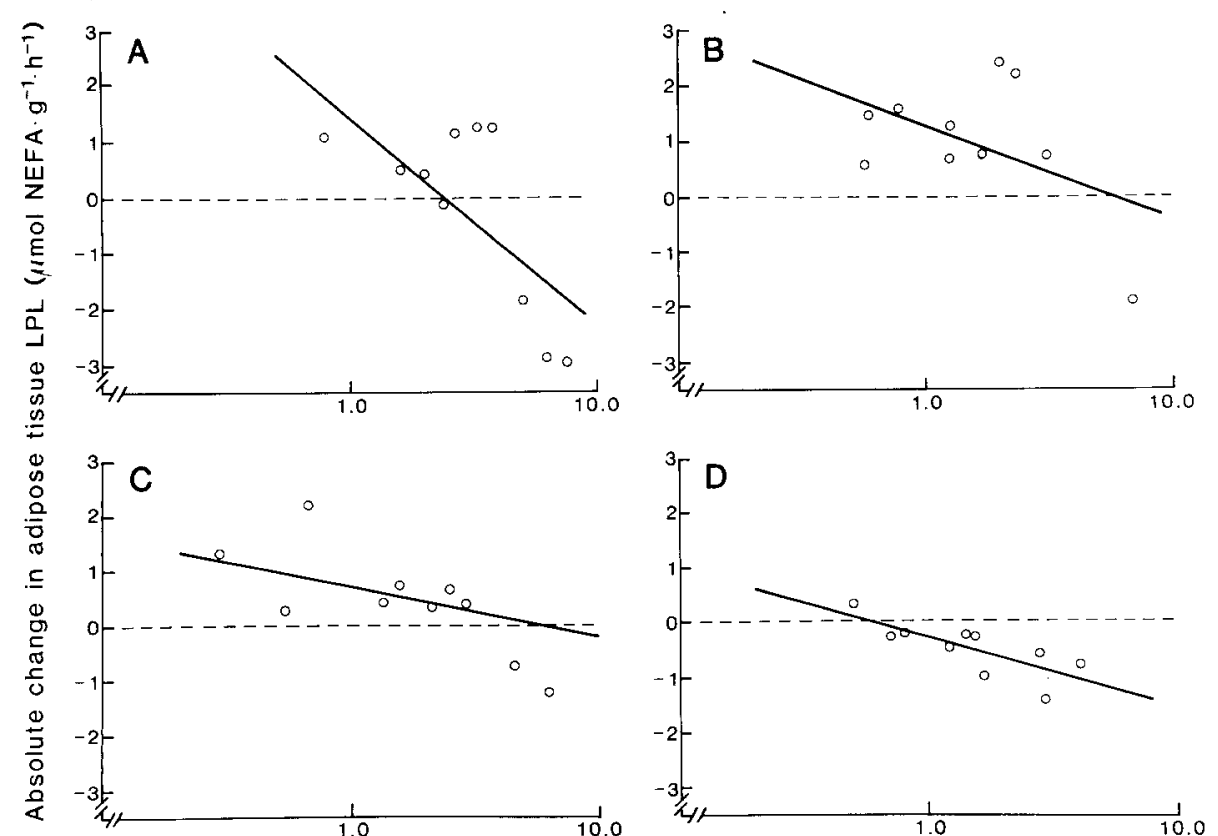

Fig. 2. Relationship between the absolute change of adipose tissue LPL and the basal enzyme activity during the 5-h euglycaemic low-dose $(r=-0.67, p<0.05, \mathrm{~A})$, and high-dose $(r=-0.48, \mathrm{NS}, \mathrm{B})$ insulin clamps, during hyperglycaemic hyperinsulinaemia $(r=-0.68, p<0.05, \mathrm{C})$ and during infusion of saline $(r=-0.75, p<0.05, \mathrm{D})$ 
Table 1. Change of lipoprotein triglyceride and cholesterol concentrations during 5-h euglycaemic hyperinsulinaemia, hyperglycaemic hyperinsulinaemia, and infusion of saline

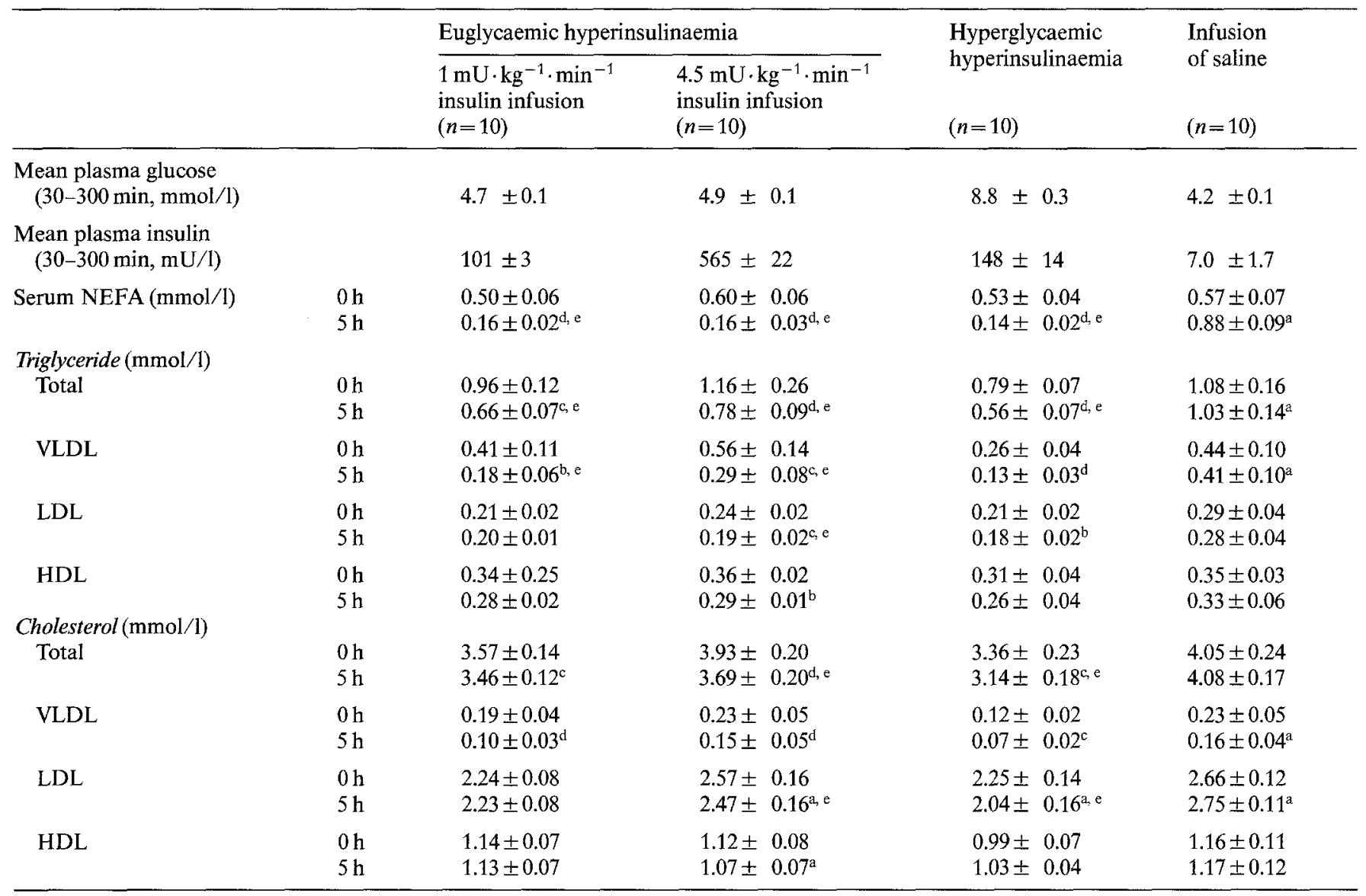

Results are expressed as mean \pm SEM. ${ }^{\mathrm{a}} p<0.05 ;{ }^{\mathrm{b}} p<0.01,{ }^{c} p<0.005,{ }^{\mathrm{d}} p<0.001$ for differences between 0 and $5 \mathrm{~h}$ (paired t-test); ${ }^{\mathrm{e}} p<0.05$ for changes during clamps versus changes during saline infusion (unpaired t-test)

$(p<0.02)$. The absolute change of LPL activity was inversely related to basal LPL level during the euglycaemic low-dose insulin clamp $(r=-0.67, p<0.05$, Fig. 2A), the hyperglycaemic clamp $(r=-0.68, p<0.05$, Fig. 2C), and during saline infusion $(r=-0.75, p<0.05$, Fig. 2D), but not during the high-insulin euglycaemic clamp ( $r=0.48$, NS, Fig. 2 B).

\section{Serum lipids and lipoproteins}

Inhibition of lipolysis as judged from the decline in NEFA levels occurred during all clamps (Table 1). During saline infusions, NEFA levels rose by $55 \%(p<$ 0.05 ). During all three clamp experiments, serum total triglyceride concentrations fell significantly. The most prominent change was seen in VLDL triglycerides, which decreased significantly during all clamps. LDL cholesterol fell significantly during both the hyperglycaemic and the high-dose euglycaemic clamps. No significant change in HDL cholesterol or HDL triglyceride or their subfractions occurred as compared to saline infusion.

\section{Relationships between glucose and lipid metabolism in the basal state and during clamps}

Neither basal LPL activity nor the change in LPL during any of the clamps correlated with the amount of glucose metabolised (M). Neither was any correlation found between the M-value and decreases in total serum triglyceride and VLDL triglyceride.

\section{Discussion}

In previous studies where adipose tissue LPL has been measured after oral glucose or a meal, no correlation between the change of LPL and the relative insulin response has been found [5-7]. In contrast, the present study shows by the use of euglycaemic insulin clamps at two insulin levels that insulin does increase activity of adipose tissue LPL in a dose-dependent manner. The concentration of insulin required for stimulation of adipose tissue LPL activity was far beyond those seen after oral feeding [5-7]. This raises the possibility that other stimulators of adipose tissue LPL, either unrelated to 
insulin or secondary to endogenous insulin release, may be present after oral feeding.

During the control saline infusion, the subjects continued fasting for $5 \mathrm{~h}$; adipose tissue LPL decreased in nine of the ten subjects studied, and the decrease was directly related to the initial enzyme activity. These changes are in keeping with our previous data demonstrating a decrease in adipose tissue LPL during caloric restriction, when the decrease in LPL was also related to the basal enzyme activity [4]. During the euglycaemic low-insulin, hyperglycaemic, and high-insulin clamps, the increases in adipose tissue LPL in $6 / 10,8 / 10$ and $9 / 10$ subjects, respectively, occurred almost exclusively when basal LPL activity was low (Fig. 2), whereas high basal LPL activities decreased during all clamps. This tendency of high LPL activities to decrease (or to remain unchanged compared with saline infusion) decreased with increasing insulin levels. This was shown during the high-insulin euglycaemic clamp, when only the highest basal LPL value decreased (Fig. 2 B). It could be argued that it is unphysiological to study changes in LPL during hyperinsulinaemia maintained by intravenous infusion. However, the intravenous route offers the possibility to study changes in LPL without interference by gut hormones, although even after oral stimuli the basal LPL activity seems to determine its response. An inverse relationship between fasting levels of adipose tissue LPL and its increase after high-carbohydrate feeding has previously been demonstrated in both normal and hypertriglyceridaemic subjects $[6,19,20]$. Patients with high fasting LPL actually had lower post-prandial levels [6]. The mechanism by which basal LPL regulates its response to insulin remains a mystery. Its physiological rôle could be to prevent excessive storage of fat in adipose tissue and, on the other hand, to promote storage of fat after a period of lipolysis such as may follow insulin deficiency in diabetics [1] or a reduction of insulin secretion during fasting [3].

Response of LPL to insulin may be related to insulin sensitivity since in obese insulin-resistant subjects, for example, LPL responses to glucose are reduced [21]. In this study, we did not observe any correlation between basal LPL activity and glucose metabolism, nor any between change of LPL and glucose metabolism. To know whether the response of LPL to insulin is related to the amount of insulin-mediated glucose metabolised, one should compare subjects with similar basal LPL levels but different degrees of insulin resistance. Here we found no significant relationships between basal LPL activities and the rates of glucose metabolism during the clamps. Thus, it appears that basal LPL activity is largely independent of insulin-mediated glucose metabolism in healthy subjects.

The most prominent change in serum lipoproteins during the induced hyperinsulinaemia was the decrease in VLDL triglyceride accompanied by a decrease in VLDL cholesterol. A significantly smaller decrease in
VLDL triglyceride also occurred during infusion of saline, probably due to continued fasting, when VLDL triglyceride is hydrolyzed by LPL in muscle [5]. The fall in VLDL triglyceride was of similar magnitude during all clamps despite marked differences in glucose and insulin levels. This indicates that a maximal decrease in circulating basal VLDL triglyceride is reached at insulin levels which are in the high physiological range. The mechanism responsible for the fall in VLDL triglyceride cannot be directly deduced from the present study. A change in VLDL merely reflects the net effects of alterations in secretion and catabolism. Under similar lowdose insulin euglycaemic clamp conditions Sadur et al. [9] observed a fall in total serum triglyceride after $80 \mathrm{~min}$ despite unchanged adipose tissue LPL. In our study, significant increase in LPL occurred only during the high-dose insulin clamp but the decrease in VLDL triglyceride was similar during all clamps. This indirectly suggests that the fall in serum triglyceride was due more to decreased secretion of VLDL than to enhanced triglyceride lipolysis by LPL.

Bazelmans et al. [22] recently showed that the magnitude of fall in plasma triglyceride concentration during euglycaemic hyperinsulinaemia is not correlated with the decrease in NEFA but is positively related to the insulin sensitivity. This indicates that in addition to decreasing plasma NEFA, insulin has more direct effects on hepatic triglyceride secretion. In our present subjects no correlation was found between fall of triglyceride and insulin sensitivity, but this may be simply related to the fact that they were lean, young individuals without insulin resistance.

Another remarkable change in lipoprotein concentrations during hyperinsulinaemia was the reduction of LDL cholesterol. Even though the percentage change was not great it was quite constant and did not occur during saline infusion. Moreover, any change which occurs during $5 \mathrm{~h}$ in a lipoprotein with a plasma half-life of several days must mean a profound change in transport kinetics. Several previous findings suggest that insulin enhances the catabolism of LDL through the highaffinity receptor pathway. Thus, insulin stimulates LDL receptor activity in vitro in human fibroblasts by increasing the receptor number [23]. A similar change occurs in vivo in mononuclear cells after $4 \mathrm{~h}$ hyperinsulinaemia [24]. The catabolism of LDL in vivo is also stimulated by hyperinsulinemia induced by total parenteral nutrition [25] or high sucrose feeding [26]. Ultimately, there is a high positive correlation between the fractional catabolic rate of LDL apolipoprotein B and plasma insulin response [27]. However, a reduction of VLDL production during acute hyperinsulinaemia may contribute to the fall of LDL since the latter originates partly as a degradation product of VLDL [28].

Acknowledgements. This study was supported by grants from the Finnish Culture and the Sigrid Juselius Foundation, the Finnish State Medical Research Council (Academy of Finland), the Foundation for 
Diabetes Research of the Finnish Diabetes Association, and Nordisk Insulinfond (Gentofte, Denmark). The help of S.-L. Karonen, Ph.D. for insulin determinations, and skillful technical assistance of Miss A. Salo, Mrs. H. Hilden, Miss P. Teräväinen, Mrs. L. Lehikoinen and Mrs. S.-L. Runeberg is greatly appreciated.

\section{References}

1. Taskinen M-R, Nikkilä EA (1979) Lipoprotein lipase activity of adipose tissue and skeletal muscle in insulin-deficient human diabetes. Relation to high density and very low density lipoproteins and response to treatment. Diabetologia 17:351-356

2. Taylor KG, Galton DJ, Holsworth G (1979) Insulin-independent diabetes: defect in the activity of lipoprotein lipase in adipose tissue. Diabetologia 16:313-317

3. Persson B, Hood B, Angervall G (1970) Effects of prolonged fast on lipoprotein lipase eluted from human adipose tissue. Acta Med Scand 188: 225-229

4. Taskinen M-R, Nikkilä EA (1979) Effects of caloric restriction on lipid metabolism in man. Atherosclerosis 32: 289-299

5. Lithell H, Boberg J, Hellsing K, Lundqvist G, Vessby B (1978) Lipoprotein-lipase activity in human skeletal muscle and adipose tissue in the fasting and fed states. Atherosclerosis 30: 89-94

6. Goldberg AP, Chait A, Brunzell JD (1980) Postprandial adipose tissue lipoprotein lipase activity in primary hypertriglyceridemia. Metabolism 29: 223-229

7. Pykälistö OJ, Smith PH, Brunzell JD (1975) Determinants of human adipose tissue lipoprotein lipase. Effects of diabetes and obesity on basal- and diet-induced activity. J Clin Invest 56: 1108-1117

8. Goldberg A, Sherrard DJ, Brunzell JD (1978) Adipose tissue lipoprotein lipase in chronic hemodialysis: role in plasma triglyceride metabolism. J Clin Endocrinol Metab 47: 1173-1182

9. Sadur CN, Eckel RH (1982) Insulin stimulation of adipose tissue lipoprotein lipase. Use of the euglycemic clamp technique. J Clin Invest 69: 1119-1125

10. McGuire EAM, Helderman JH, Tobin JD, Andres R, Berman R (1976) Effects of arterial versus venous samples: an analysis of glucose kinetics in man. J Appl Physiol 41: 565-574

11. DeFronzo RA, Tobin JD, Andres R (1979) Glucose clamp technique: a method of quantifying insulin secretion and resistance. Am J Physiol 237: E214-E223

12. Taskinen M-R, Nikkilä EA, Huttunen JK, Hilden H (1980) A micromethod for assay of lipoprotein lipase activity in needle biopsy samples of human adipose tissue and skeletal muscle. Clin Chim Acta 104: 107-117

13. Havel RJ, Eder HA, Brabdon JH (1955) The distribution and chemical composition of ultracentrifugally separated lipoproteins in human serum. J Clin Invest 34: 1345-1353
14. Desbuquois B, Aurbach GD (1971) Use of polyethylene glycol to separate antibody-bound peptide hormones in radioimmunoassay. J Clin Endocrinol Metab 33: 732-738

15. Wahlefeld AW (1974) Triglycerides: determination after enzymatic hydrolysis. In: HV Bergmeyer (ed) Methods of enzymatic analysis, 2 edn. Academic Press, New York, pp 1831-1835

16. Mosinger F (1965) Photometric adaptation of Dole's microdetermination of free fatty acids. J Lipid Res 6: 157-159

17. Dixon WJ (ed) (1981) BMDP statistical software 1981. University of California Press, Berkeley

18. Swinscow TDW (1981) Statistics at square one. British Medical Association, London

19. Nilsson-Ehle P, Carlström S, Belfrage P (1975) Rapid effects on lipoprotein lipase activity in adipose tissue of humans after carbohydrate and lipid intake. Scand J Clin Lab Invest 35: 373-378

20. Brunzell JD, Schwarz RS, Eckel RH, Goldberg AP (1981) Insulin and adipose tissue lipoprotein lipase activity in humans. Int $\mathrm{J}$ Obesity 5: 685-694

21. Taskinen M-R, Nikkilä EA (1981) Lipoprotein lipase in adipose tissue and skeletal muscle in human obesity: response to glucose and to semistarvation. Metabolism 30:810-817

22. Bazelmans J, Nestel PJ, Nolan C (1983) Insulin-induced glucose utilization influences triglyceride metabolism. Clin Sci 64: $511-516$

23. Chait A, Bierman EL, Albers JJ (1979) Low-density lipoprotein receptor activity in cultured human skin fibroblasts. J Clin Invest 64: $14 \mathrm{~A}$

24. Mazzone T, Foster D, Albers JJ, Chait A (1982) Low density lipoprotein catabolism is enchanced by insulin. Diabetes 31 (Suppl 2): $14 \mathrm{~A}$

25. Chait A, Foster D, Miller DG, Bierman EL (1981) Acceleration of low-density lipoprotein catabolism in man by total parenteral nutrition. Proc Soc Exp Biol Med 168: 97-104

26. Nestel PJ, Reardon M, Fidge NH (1979) Sucrose-induced changes in VLDL- and LDL-B apoprotein removal rate. Metab Clin Exp 28: $531-535$

27. Kissebah AH, Alfarsi S, Evans DJ, Adams PW (1983) Plasma low density lipoprotein transport kinetics in noninsulin-dependent diabetes mellitus. J Clin Invest 71: 655-667

28. Eisenberg S (1980) Origin of plasma low and high density lipoprotein. In: Gotto VAM, Smith LC, Allen B (eds) Atherosclerosis. Springer, New York, pp 146-151

Received: 25 August 1983

and in revised form: 18 June 1984

Dr. Hannele Yki-Järvinen

Third Department of Medicine

University of Helsinki

SF-00290 Helsinki 29

Finland 